\title{
PENGARUH INFLASI DAN PRODUK DOMESTIK REGIONAL BRUTO (PDRB) SEKTOR PERTANIAN TERHADAP NILAI TUKAR PETANI DI PROVINSI ACEH TAHUN 2008-2019
}

\author{
Jumilah *a, Devi Andriyani ${ }^{* b}$, Fanny Nailufuar *c \\ ${ }^{a}$ Fakultas Ekonomi dan Bisnis Universitas Malikussaleh \\ * Corresponding author : deviandriyani@unimal.ac.id \\ * fannynailufar@unimal.ac.id jumilaarga11@gmail.com
}

A R T I C L E I N FO RMA T IO N

\section{Keywords:}

Inflation, Agricultural Sector GRDP, Farmers Exchange Value, Farmers Exchange Rate.

\begin{abstract}
A B S T R A C T
This study examined the influence of inflation and PRDB in the agricultural sector on farmer exchange rates in Aceh province. The data used was quantitative data with a time-series approach from 2008 to 2019. The analytical method used was Multiple Linear Regression. Partial test results showed that inflation did not affect Farmer Exchange Rates, while GRDP in the Agricultural Sector negatively and significantly influenced Farmer Exchange Rates. Furthermore, the simultaneous test results showed that inflation and GDP in the agricultural sector positively and significantly influenced Aceh Farmer Exchange Rate. The determination coefficient (R2) was 0.5233 , which indicated that the ability of the independent variables to explain the dependent variable was $51.33 \%$, while the remaining $48.67 \%$ was influenced by other variables outside the model. The results of the correlation coefficient obtained in this study are $R=\sqrt{ } R 2=\sqrt{ } 0.6018=0.7757$. So it concluded that inflation and GRDP in the Agricultural Sector had a significant and positive relationship to the Farmer Exchange Rate because the correlation value of $77.57 \%$ was almost close to a positive one (1).
\end{abstract}

\section{PENDAHULUAN}

Pembangunan disegala bidang merupakan arah dan tujuan kebijakan Pemerintah Indonesia.Adapun hakikat sosial dari pembangunan itu sendiri adalah peningkatan kesejahteraan bagi seluruh penduduk Indonesia. Mengingat bahwa sebagian besar penduduknya Indonesia tinggalnya di daerahnya pedesaannya dengan mata pencaharian bertumpu pada sektornya pertanian, makanya sangat diharapkannya sektornya pertaniannya ini dapatnya merupakan motornya penggerak pertumbuhannya yang mampunya meningkatkannya pendapatan para petani dan mampu mengentaskan kemiskinan (Nirmala et al., 2016).

Berikut adalah perkembangan pada nilai PDRB pertanian, tingkat inflasi dan nilai tukar petani yang ada di provinsi Aceh 2015-2019.

Tabel 1

Perkembangan NTP, Inflasi dan PDRB sektor Pertanian Provinsi AcehTahun 2015-2019

\begin{tabular}{|c|r|r|r|}
\hline Tahun & $\begin{array}{c}\text { NTP } \\
(\boldsymbol{\%})\end{array}$ & \multicolumn{1}{|c|}{$\begin{array}{c}\text { Inflasi } \\
(\mathbf{\%})\end{array}$} & \multicolumn{1}{c|}{$\begin{array}{c}\text { PDRB } \\
(\boldsymbol{\%})\end{array}$} \\
\hline 2015 & 96.63 & 1.53 & 29.13 \\
\hline 2016 & 96.27 & 3.95 & 29.39 \\
\hline 2017 & 94.75 & 4.25 & 29.74 \\
\hline 2018 & 94.73 & 1.84 & 29.74 \\
\hline 2019 & 92.28 & 1.69 & 29.54 \\
\hline
\end{tabular}

Sumber: BPS Aceh, 2020.

Berdasarkan tabel 1.1 di atas dapat dilihat bahwa Nilai Tukar Petani (NTP), inflasi, dan PDRB sektor pertanian di Provinsi Aceh cenderung fluktuatif. Dimana secara umum terlihat bahwa NTP setiap tahunnya mulai mengalami penuruan bahkan nilainya berada dibawah 100 , halnya ini dapatnya dilihatnya pada tahun 2015 NPT Aceh tercatat sebesar $96.63 \%$ dan terus menurun hingga tahun 2019 menjadi sebesar 92.28\%.Nilai NTP yang berada dibawah 100 memberikan gambaran bahwa tingkat kesejahteraan masyarakat aceh sangat rendah, dan hal ini harus adanya perhatian khusus dan tindak lanjut dari pemerintah Aceh.

Jika dikaitkan dengan perkembangan inflasi yang terjadinya di Aceh Secara teoritis diungkapkan bahwa peningkatan inflasi akan menyebabkan nilai tukarnya petani yakni indeksnya harganya yang dibayarkan petani akan mengalami peningkatan, sedangkan indeks harga yang diperoleh petani tetap karena tidak diikutinya dengan kenaikannya harga gabahnya. 
Berdasarkan data tahun 2017 dapat dilihat bahwa nilai inflasi berada pada tingkat tertinggi yakni 4,25\%, namun nilai tukar petani semakin rendah berada pada angka 94.75\%, hal ini disebabkan karena harga jual gabah ditingkat petani tidak mengalami kenaikan meskipun harga kebutuhan pokok ikut naik, hal ini menyebabkan pendapatannya yang diterimanya petani tidak mencukupi untuk memenuhinya kebutuhannya pokok dan modal bertani.

Faktor inflasi dapat mempengaruhi Nilai Tukar Petani (NTP) dimana tingginya tingkat inflasi menyebakan petani tidak mampu membeli sarana produksi pertanian. Petani harus menghemat dan sebagian menggunakan sarana produksi alternatif meskipun kurang berkualitas. Dampak yang terjadi, menurunnya jumlah produksi yang berakibat nilai tukar petani menjadi rendah.

Faktor selanjutnya adalah PDRB sektor pertanian. Sebagimana yang kita ketahui bahwa PDRB sektor pertanian sangat berpengaruh penting dalam perkembangan NTP, Secara teoritis nilai tukar petani mempunyai kegunaan untuk mengukur kemampuan tukar barang dijual petani dengan produk yang dibeli petani pada kebutuhan rumah tangga. Kenaikan pendapatan bruto sektor pertanian khususnya mengindikasikan jika pendapatan petani mengalami peningkatan. Hal yang berbeda terjadi pada tahun 2016 dimana nilai PDRB sektor pertanian tercatat sebesar 29.13\% dan terus meningkat hingga tahun 2018 sebesar $29.74 \%$ namun nilai tukar petani justru mengalami penurunan yaitu sebesar $96.63 \%$ ditahun 2016 dan semakin rendah sampai tahun 2018 sebesar 94,73\%, sedangkan tahun 2019 PDRB sektor pertaniannya dan Nilai Tukarnya Petani sama-sama mengalami penurunan.

Penelitian ini bertujuan untuk mengetahui dan menganalisis Pengaruh Inflasi dan PDRB Sektor Pertanian Terhadap Nilai Tukar Petani di Provinsi Aceh.

Selanjutnya bagian kedua dari penelitiannya ini akannya membahas tinjauan teoritis, metode penelitian akan dibahas pada bagian ketiga. Kemudian pada bagian ke empat akan dibahas hasil penelitian dan pembahasan. Pada bagiannya kelima akan membahas kesimpulan dannya saran.

\section{TINJAUAN TEORITIS}

\section{Nilai Tukar Petani}
Alat ukur kemampuan tukar barang barang
(produk) pertanian yang dihasilkannya petani terhadapnya barang dan jasanya yang diperlukannya untuknya konsumsi rumah tangganya dan kebutuhannya dalam memproduksi hasil pertanian adalah definisi dari Nilai tukar petani. NTP juga diartikan angka perbandingannya antara indeksnya harga yang diperoleh

petaninya dengan indeksnya harga yang dibayarnya petani (BPS Aceh, 2019).

Faridah Nurul (2016) menyebutkan bahwa Nilai Tukarnya Petani adalah perbandingan atau rasionya antara indeksnya harga yangnya diterima petaninya dengan indeksnya harganya yang dibayarnya petani.

semakin tinggi tingkat NTP maka semakin tinggi tingkat kesejahteraan dan kehidupan petani. Hal ini dikarenakan dengan adanya peningkatan nilai tkar petni maka kemampuan petani untuk melakukan belanja keperluan pendidikan, kesehatan, dan kebutuhan rumah tangga yang lain dapat terpenuhi, begitupun sebaliknya. Menurunnya nilai tkar petni menunjukan bhwa kesejahteraan petani menurun dan pendapatannya berkurang, sehingga upaya untuk meningkatkan kualitas SDM dan tingkat IPM pun juga akan menurun (andriyani devi \& mulia eka, 2020)

\section{Inflasi}

Menurut Herlianto (2013) inflasi merupakan suatu gejala yang menunjukkan harga-harga mengalami kenaikan secara umum. Secara sederhnana inflasi diartikan sebagai keadaan meningkatnya harga secaranya umumnya dan terus menerus.Kenaikan harga dari satu atau dua barang saja tidak dapat disebut inflasi kecuali jika kenaikkan inflasi tersebut meluass (atau menyebabkan kenaikan harga) pada barang lainnya. Perhitungan inflasi dlakukan dalam rentang waktu minimal bulanan (Wardhani, Kusuma, 2017).

Salah satu peristiwa modern yang sangatnya penting dan yang selalu dijumpai dihampir semua negara di dunia adalah inflasi. Definisi singkat dari inflasi adalahnya kecenderungannya harga-harganya untuk menaiknya secaraumum dan terusnya menerus, hal ini tidak berarti bahwa hargaharga berbagai macam barang itu naik dengan presentase yang sama. Mungkin kenaikan tersebut dapat terjadi tidak bersamaannya, yang pentingnya terdapat kenaikannya harga umumnya barangnya secaranya terus menerusnya selama satu periode tertentu. Kenaikannya yang terjadinya sekali sajanya meskipunnya dalam presentasenya yang besarnya, bukanlah merupakannya inflasinya (Mankiw N, 2006). 


\section{Produk Domestik Regional Bruto (PDRB)}

Indikator pentingnya untuknya dapat mengetahuinya kondisi ekonominya suatu daerahnya dalam kurunnya waktu tertentunya ialah menggunakan Produk Domestik Regional Bruto (PDRB), dapat menggunakan atasnya dasar harganya berlaku ataupun atas dasarnya harga konstannya. Menurutnya Sukirno (2012) pertumbuhannya ekonomi merupakannya kenaikan outputnya per kapitanya dalam jangkanya yang panjangnya, penekanannya ialahnya pada tiganya aspek yakni prosesnya, outputnya per kapitanya, serta jangkanya panjang. Pertumbuhan ekonomi merupakan proses, bukan hanya gambaran ekonomi sesaat. Pembangunan daerah serta pembangunan sektoral harus dilaksanakan sejalan agar pembangunan sektoral yang beradanya di daerah-daerah dapat berjalan sesuainya dengan potensi serta prioritas daerah.

Produk Domestik Bruto (PDB) merupakannya salah satunya indikatornya makro ekonomi yang padanya umumnya digunakannya untuk mengukurnya kinerja ekonominya di suatu negaranya. Sedangkan untuknya tingkat wilayahnya, baiknya di tingkatnya wilayahnya propinsi maupunnya kabupaten ataunya kota digunakannya Produk Domestik Regional Bruto (PDRB). PDRB merupakannya bagian darinya PDB, sehingganya perubahannya PDRB yang terjadinya ditingkatnya regional akannya berpengaruhnya terhadapnya PDB atau sebaliknya Raharjonya (Simanjuntak \& Bhakti, 2018).

\section{Kerangka Konseptual}

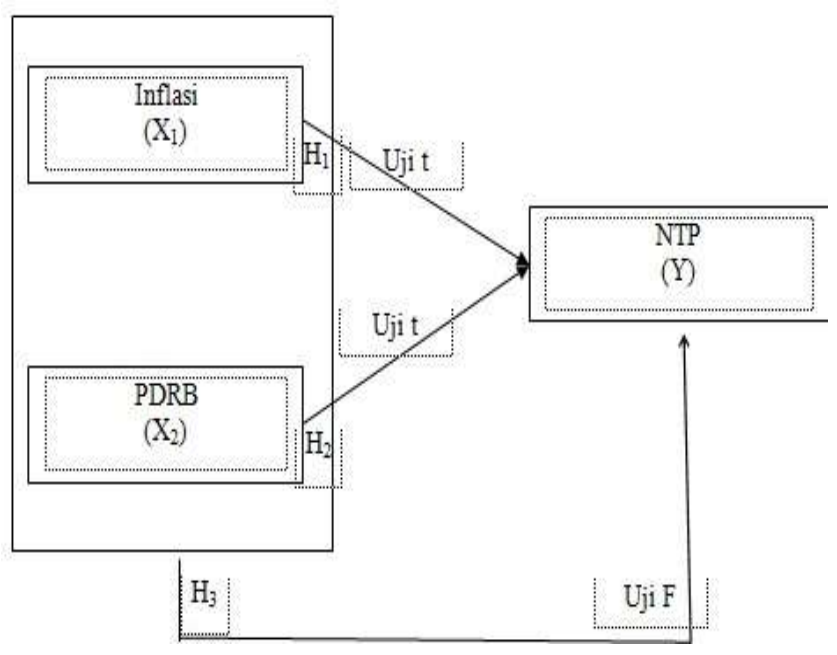

Gambar 1.

\section{Kerangka Konseptual}

Kerangka konseptual gambar 1 di atas menjelaskan pengaruh antara variabel bebas dan variabel terikat, yaitu pengaruh inflasi (x1) dan produk domestic regional bruto (x2) terhadap nilai tukar petani (y) yang akan di uji secara parsial dengan mengguakan uji $t$, dan secara bersama-sama seluruh variabel independen terhadap dependen dengan menggunakan uji $\mathrm{f}$.

\section{Hipotesis}

Adapun hipotesis alternatif yang diberikannya dalam penelitiannya ini adalahnya sebagainya berikut :

$\mathrm{H}_{1}=$ Diduga inflasi berpengaruh Negatif dan Signifikan terhadap Nilai Tukar Petani di Provinsi Aceh.

$\mathrm{H}_{2}=$ Diduga PDRB Sektor Pertanian berpengaruhnya Negatif dan Signnifikan terhdap Nilai TukarPetani di Provinsii Aceh.

$\mathrm{H}_{3}=$ Diduga Inflasi dan PDRB Sektor Pertanian berpengaruhnya positif dannya Signifikan terhadapnya Nilai Tukar Petani Provinsi Aceh.

\section{METODE PENELITIAN}

\section{Data dan Sumber Data}

Penelitiannya ini menggunakannya data sekunder, yang dimaksudnya dengan data sekunder adalah data yang telah diolah oleh pihaknya lain. Data yang digunakan dari tahun 2008 sampai 2019. Data utama di dalam penulisan proposal ini bersumber dari Badan Pusat Statistik (BPS).

\section{Definisi Operasionalisasi Variabel}

Operasionalisasi variabel merupakan petunjuk bagaimana variabel-variabeldalam penelitian diukur. Untuk memperjelasnya dan mempermudahnya pemahamannya terhadap variabel-variabelnya yang akannya dianalisisnya dalam penelitiannya ini, maka butuhnya dirumuskan operasionalisasinya variabelnya yaitu sebagainya berikut:

\section{Variabel Dependen (Y)}

Variabel dependen adalah variabel terikat yang artinya variabelnya yang dipengaruhinya oleh variabel bebas. Variabel dependen dalam penelitiannya ini yaitu Nialai Tukar Petaani (NTP) yang artinya adalah Raiso antara harga yang didapat petani dengan harganya yang dibayarnya petani, NTP dalam peneitian ini diambil dari total nilai tukarnya petani yang diukur dalam satuan persen 


\section{Variabel Independen $(\mathrm{X})$}

Variabel Independen adalah variabel bebas yang artinya variabel yang perubahannya mempengaruhi variabel terikat. Dalam penelitiannya ini variabelnya independen terdiri atas :

a) Inflasi $\left(\mathrm{X}_{1}\right)$ adalah suatu keadaannya dimana terjadinya peningkatan harga-harga secara umumnya dan terus menerus dalam wkatu atau tempo jangka panjang. Inflasi diambil dari jumlah inflasi 43 kotanya di indonesiia yang diukur dalam satuan persen $(\%)$

b) PDRB Sektor Pertanian $\left(\mathrm{X}_{2}\right)$ adalah Nilai tambahnya bruto atau penjumlahan dari nilainya output bersih yang tercipta di wilayah domestik (provinsi) pada suatu periode waktunya tertentu. Dalam penelitiannya ini PDRB diambil dari data PDRB menurut lapangan usaha jenis sektor pertaniannya yang diukur dalam satuan (\%).

\section{Metode Analisis Data}

Untuk menganalisis pengaruh variabel bebas dan variabel terikat digunakan teknik regresi linear berganda dengan formula OLS (Ordinary Least Quare), yaitu :

$$
\mathrm{Y}=\alpha+\beta 1 \times 1+\beta 2 \times 2+e i
$$

Dimana :

Y : Nilai Tukar Petani

$\mathrm{X}_{1}$ : Inflasi

$\mathrm{X}_{2}$ : PDRB Sektor Pertanian

ei : Error Term

\section{Uji Normalitas}

Menurut Gujarati (2009), menyebutkan bahwa ujinya normalitas adalahnya suatu pengujian dimana jika probabilitasnya lebih besar daripada alpha 5 persen maka uji normalitas diterima. Justifikasi lainnya untuk uji ini adalah dengan membandingkan nilai J-B hitung dengan $\mathrm{x} 2$ tabel, apabila alpha J-B <x2 tabel maka residual terdistribusi normal. Sedangkan menurut Sunyoto (2011), uji normalitas adalah pengujian yang akan menguji data variabel bebas (x) dan data variabel terikat (y) pada persamaan regresi yang dihasilkan berdistribusi normal atau berdistribusi tidak normal.

Model regresi yang baik merupakan berdistribusi data normalnya atau mendekatinya normal.Metode yang sering digunakan untuk melakukannya uji normalitasnya adalah dengan uji Jarque- bera. Pengujian ini dapat dilakukannya dengan program EVIEWS sehingga nantinya memperoleh nilai probabilitas ( $p$-value). Jika nilai probabilitasnya lebih besarnya dari $5 \% \quad(<0,05)$, berarti nilai residualnya berdistribusinya normal. Sebaliknya, jika nilainya probabilitas lebihnya kecil darinya $5 \%(<0,05)$, berarti nilai residualnya berdistribusi tidak normal.

\section{Pengujian Asumsi Klasik}

Dalam melakukannya estimasi

persamaannya linier dengannya menggunakannya metodenya OLS, makanya asumsi-asumsinya dari OLS harusnya dipenuhi.

Berdasarkan keadaannya tersebut didalamnya ilmu ekonometrikanya agar suatunya model dikatakannya baik makanya perlu dilakukannya pengujiannya sebagai berikutnya :

\section{Uji Autokorelasi}

Menurut Ghozali (2006), ada beberapa cara yang dapat digunakan untuk melihat terjadi atau tidaknya Autokorelasi. Salah satunya dengannya Uji BreuschGodfrey Serial LM Test.

\section{Uji Multikolineritas}

Multikolineritas adalahnya suatu kondisinya dimana terjadinya korelasinya yang kuatnya diantaranya variabelvariabelnya (x) yang di ikutnya sertakan dalamnya pembentukannya model regresinya linear (Gujarati, 2006). Uji multikolineritas dilakukan untuk melihatnya apakah dalam model regresinya ditemukannya adanya korelasinya antar variabelnya bebas (x).Jika terjadi korelasi yang tinggi, maka regresi tersebut terjadi multikolineritas.

Untuk mengetahui multikolineritas dengan menggunakan Eviews dapat dilakukannya dengan melihatnya korelasi antar variabel bebas (Correlation Matrik). Jika korelasi antara variabelnya bebas lebih atau samanya dengan $0,8 \quad(<0,8)$, berarti terjadi multikolineritas.

\section{Uji Heteroskedastisitas}

Heteroskedastisitas adalahnya
variabel pengganggunya memilikivariannya yang berbedanya dari satunya observasinya ke observasinya lainnya ataunya varian antarnya variabel independennya tidak samanya, hal ininya melanggar asumsinya homokedastisitasnya yaitu setiapnya variabel penjelas memiliki variannya yang samanya (konstan). Uji heteroskedastisitas dapat dilakukannya dengan Uji White, yaitu dengan melihatnya nilai obs*R-Square dan nilai signifikansi di atas tingkat $\alpha=5 \%$ atau harus lebih besarnya dari $(>0,05)$ sehingga dapatnya disimpulkan bahwanya model regresinya tidak 
mengandung adanya Heteroskedastisitas (Ghozali, 2012).

\section{Pengujian Statistik}

Untuk menguji kebenaran model regresi diperlukan pengujian statistik diantaranya :

\section{Uji t-Statistik}

Menurut Ghozali (2006), uji statistic atau uji t bertujuan untuknya melihat signifikan dari pengaruh variabel bebasnya secara individual terhadap variabelnya terikat dengannya menganggap variabelnya bebasnya lainnya adalahnya konstan.

1. Jika $\mathrm{t}$ hitung $>\mathrm{t}$ tabel, maka variabel penjelas secara individual mempengaruhi variabel yang dijelaskan secara signifikan.

2. Jika $\mathrm{t}$ hitung $<\mathrm{t}$ tabel, maka variabel penjelas secara individual tidak mempengaruhi variabel yag dijelaskan secara signifikan.

\section{Uji F-statistik}

Untuk menentukan tingkat signifikan secara keseluruhan pada tingkat kepercayaan sebesar 95\%, pengujian hipotesis dengan uji F. Gujarati (2006), uji F dilakukan dengannya membandingkan antara $\mathrm{F}$ hitungnya dengan $\mathrm{F}$ table, apabila $\mathrm{F}$ hitung $>\mathrm{F}$ table, dicari di tabel $\mathrm{F}$ dengan patokan taraf signifikan 5\%, artinya bahwa $\left(\mathrm{X}_{1}\right),\left(\mathrm{X}_{2}\right)$, dan $\left(\mathrm{X}_{3}\right)$, secara bersamasama mempengaruhi $(\mathrm{Y})$.

\section{Koefisien Determinasi}

Koefisien ini nilainya antara 0 (nol) sampai dengan 1 (satu).Semakin besar nilai koefisien tersebut maka variabel-variabel independen lebih mampu menjelaskan variasi variabel dependen. Nilai koefisiennya determinasi merupakannya suatu ukurannya yang menunjukkannya besar sumbangannya dari variabelnya independen terhadapnya variabel dependennya, atau dengannya kata lain koefisiennya determinasinya mengukur variasi turunan $\mathrm{Y}$ yang diterangkannya oleh pengaruhnya $X$. Bila nilainya koefisiennya dterminasi yang diberi symbol $\mathrm{R}^{2}$ mendekatinya angkanya 1 , maka variabelnya independennya makin mendekatinya hubungannya dengan variabelnya dependen (Gujarati, 2009).

Adapun kegunaannya koefisien determinasinya adalah:

1. Ukuran mengukur proporsi atau presentasenya dari jumlahnya variasinya yang diterangkannya oleh modelnya regresi ataunya untuk mengukurnya besar sumbangannya dari variabelnya $\mathrm{X}$ terhadapnya variabel Y.

2. Hasil darinya analisisnya ini dinyatakan dalam presentasi batas-batas determinasi sebagi berikut : $0<>>^{2}<1$.
3. Untuk mengetahui nilai koefisiennya determinasi, mak dapat dihitung dengan cara mengkuadratkan nilai koefisien korelasi $\left(\geqslant>^{2}\right)$.

\section{Koefisien Korelasi}

Koefesien korelasi dinyatakan dalam nilai koefisiennya korelasi (R), Koefisien Kolerasi ini bertujuannya untuk melihat seberapa besar tingkat kekuatan hubungannya antaranya variabel independen dengan variabelnya dependen. Menurut Ghozali (2012) terdapat beberapa ketentuan dalam menginterpretasikan hasil koefisien kolerasi, diantaranya yaitu :

1) Jika koefisien korelasi bernilai 0,00 sampai 0,199 (plus atau minus) menunjukkan derajat hubungan yang sangat rendah,

2) Jika koefisiennya korelasi bernilai 0,20 sampai 0,399 (plus atau minus) menunjukkan derajat hubungan yang Rendah,

3) Jika koefisiennya korelasi bernilai 0,40 sampai 0,599 (plus atau minus) menunjukkan derajat hubungan yang Sedang,

4) Jika koefisiennya korelasi bernilai 0,60 sampai 0,799 (plus atau minus) menunjukkan derajat hubungan yang tingginya atau kuat,

5) Jika koefisien korelasi bernilai 0,80 sampai 1,00 (plus atau minus) menunjukkan derajat hubungan yang tingginya atau kuat.

\section{HASIL PENELITIAN DAN PEMBAHASAN}

\section{Hasil Penelitian}

\section{Hasil Analisis Regresi Liniear Berganda}

Regresi liniear berganda bertujuannya untuk mengetahuinya ada tidaknya pengaruh signifikan dua ataunya lebih variabelnya bebas terhadap variabel terikat (Y). Untuk melihatnya adanya tidaknya pengaruh dapat dilihat melalui uji asumsi klasik.

\section{Hasil Uji Normalitas}




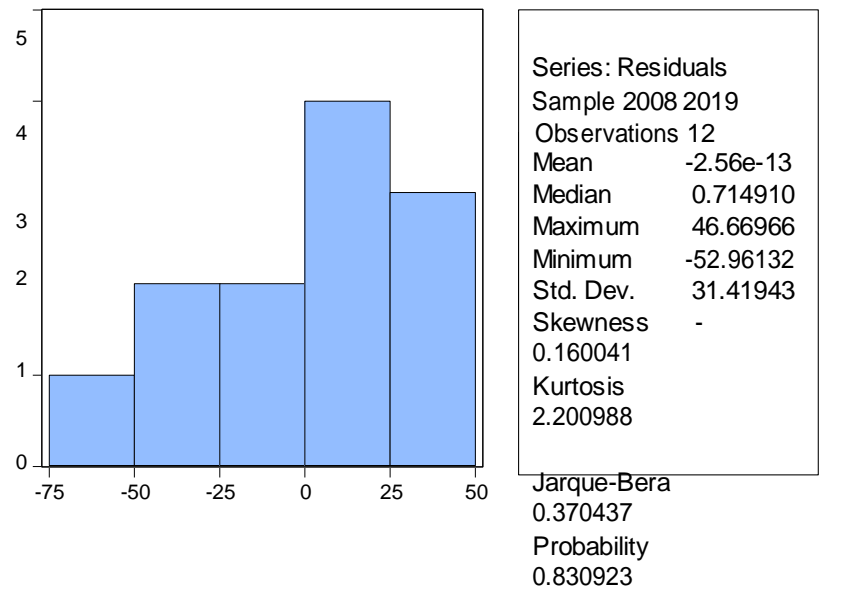

Sumber: Data Diolah (2020)

\section{Gambar 2}

\section{Histogram-Hasil Uji Normalitas}

Berdasarkan Gambar 2 diatas dapat dilihat bahwa data penelitiannya ini telah terdistribusi secaranya normal. Hal ininya dapat dibuktikannya dengan melihat perbandingan nilai Jarqu-Berra $<$ ChiSquare Tabel yaitu $0.37<7.81$ dengan nilaiprobabilitas Jarqu-Berra> taraf signifikan 5\% (0.05)yaitusebesar $0.8309>0.05$. hasil penelitiannya ini sejalannya dengan teori yang dinyatakan oleh (Ghozali, 2012) apabila nilai Jarqu-Berra < Chi-Square dan probabilitas JarquBerra > taraf signifikan 5\% (0.05) maka data sudah terdistribusi dengan normal.

\section{Hasil Uji Asumsi Klasik}

Berikut hasil uji asumsi klasik :

\section{Hasil Uji Autokorelasi}

Adapun hasil pengujian sebagai berikut :

Tabel 2

\section{Hasil Uji Autokorelasi}

\begin{tabular}{|c|c|c|}
\hline \multicolumn{2}{|c|}{ Breusch-Godfrey Serial Correlation LM Test: } & \\
\hline F-statistic & 2.925274 Prob. $F(2,7)$ & 0.1193 \\
\hline Obs*R-squared & 5.463314 Prob. Chi-Square(2) & 0.0651 \\
\hline
\end{tabular}

Sumber: Hasil Olah Data,2020

Berdasarkan Tabel 2 diatas terlihat bahwa hasil penelitian ini terbebas dari indikasi Autokolerasi, hal ininya dapat dilihatnya pada nilai Obs*R-squared < ChiSquare Tabel yaitu $5.463314<7.81$ dan probablitas Obs*R-squared > taraf signifikan $5 \%(0,05)$ yaitu 0.06 $>0,05$.

\section{Uji Multicoliniearitas}

Adapun hasil pengujian sebagai berikut :

\section{Tabel 3}

\section{Hasil Uji Multicoliniearitas}

\begin{tabular}{|c|c|c|}
\hline \multicolumn{2}{|c|}{} & \multicolumn{2}{|c|}{} \\
\hline Variabel & INFLASI & $\begin{array}{c}\text { PDRB_PERTA } \\
\text { NIAN }\end{array}$ \\
\hline $\begin{array}{c}\text { PDRBASI } \\
\text { AN }\end{array}$ & 1.000000 & -0.499962 \\
\hline
\end{tabular}

Sumber : Hasil Olah Data,2020

Berdasarkan

hasil

uji

multikolinearitas menunjukkan bahwa tidaknya terdapat variabel yang memiliki

nilai lebih dari 0,8. Dengan demikian dapat disimpulkannya bahwa dalamnya penelitiannya ini tidaknya terjadi multikolinearitas.

\section{Hasil Uji Heteroskedastisitas}

Tabel 4

\section{Hasil Uji Heteroskedastisitas}

\begin{tabular}{|c|c|c|c|}
\hline \multicolumn{3}{|c|}{ Heteroskedasticity Test: White } & \\
\hline & & 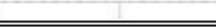 & \\
\hline F-statistic & 1.808398 & Prob. $F(2,9)$ & 0.2187 \\
\hline Obs*R-squared & 3.439983 & Prob. Chi-Square(2) & 0.1791 \\
\hline Scaled explained SS & 1.161950 & Prob. Chi-Square(2) & 0.5594 \\
\hline
\end{tabular}

Sumber : Hasil Olah Data,2020

Berdasarkan hasil pengujian heteroskedastisitas pada tabel 4 diatas terlihat bahwa model dalam penelitian ini sudah terbebas dari indikasi heteroskedastisitas.Hal ini terbuktinya dari nilai $\mathrm{Obs}^{*} \mathrm{R}$-squared $<$ Chi-Square Tabel yaitu $3.439983<7.81$ dan juga nilai Probabilitas Chi-Square > taraf signifikansi $5 \%$ yaitu $>0.1791$.

\section{Hasil Uji Hipotesis}

Adapun hasil pengujian yaitu :

Tabel 5

Hasil Uji Regresi Liniear Berganda

\begin{tabular}{|c|rrrr|}
\hline \hline \multicolumn{1}{c}{ Variable } & Coefficient & Std. Error & t-Statistic & Prob. \\
\hline \hline C C & 1734.707 & 159.6372 & 10.86656 & 0.0000 \\
\hline INFLASI & -4.115053 & 4.299457 & -0.957110 & 0.3635 \\
\hline PDRB PERTANIAN & -19.51945 & 5.477659 & -3.563466 & 0.0061 \\
\hline \hline R-squared & 0.601851 & Mean dependent var & 1185.892 \\
\hline Adjusted R-squared & 0.513374 & S.D. dependent var & 49.79384 \\
\hline S.E. of regression & 34.73549 & Akaike info criterion & 10.14572 \\
\hline Sum squared resid & 10858.99 & Schwarz criterion & 10.26695 \\
\hline Log likelihood & -57.87431 & Hannan-Quinn criter. & 10.10084 \\
\hline F-statistic & 6.802308 & Durbin-Watson stat & 0.569681 \\
\hline Prob(F-statistic) & 0.015856 & & \\
\hline \hline
\end{tabular}

Sumber: Hasil Olah Data, 2020 
Berdasarkan tabel 5 diatas persamaan regresi linear berganda yaitu :

$$
Y=\alpha+\beta_{1} X_{1}+\beta_{2} X_{2}+e
$$

Dan jika dikaitkannya dengan hasil penelitiannya ini makanya diperoleh :

$\mathrm{Y}=1734.707$ - 4.115053 Inflasi - 19.51945 PDRB_Pertanian + e

Dari hasil diatas maka interprestasi model regresi linearnya bergandanya adalah sebagainya berikut :

Kostanta sebesar 1734.707 yang artinya apabila inflasi dan PDRB Sektor pertanian bernilai konstan atau (0) maka Nilai Tukar Petani juga akan konstan sebesar 1734.707 satuan atau $17.34707 \%$.

Koefisien Variabel Inflasi bernilai negatif sebesar 4.115053 yang artinya apabila inflasi mengalami kenaikan sebesar satu persen maka akan membuat Nilai Tukar Petani menurun sebesar 4.115053 atau $4.11 \%$ dengan asumsi variabel PDRB Sektor Pertanian bernilai konstan.

Selanjutnya koefisien PDRB Sektor Pertanian bernilai negatif sebesar-19.51945 yang artinya apabila PDRB Sektor Pertanian mengalami kenaikan sebesar satu persen maka Nilai Tukar Petani akan menurun sebesar 19.51945 atau $19.51 \%$ dengan asumsi variabel infasi bernilai konstan.

\section{Hasil Uji t-Statistik}

Ghozali (2012) menyatakan untuk mengetahuinya pengaruh variabelnya bebas secaranya parsial atau individu terhadap variabel tidak bebasdengan asumsi variabelnya yang lainnya konstan. Pengujiannya ini dilakukannya dengan melihat derajat signifikan masing-masingnya variabelnya bebas menggunakan alat bantu Eviews, ujinya ini dilakukannya dengan membandingkan nilai thitung dengan ttabel dengan rumusan yaitu df $(n-k)=(12-3)=$ 9 pada taraf signifikan a 5\% $(0,05)$ yaitu 2.26216 .

Adapun hasil pengujian hipotesis pada tabel 4.4 diatas dalam penelitiannya ini yaitu :

Variabel Inflasi $\left(\mathrm{X}_{1}\right)$ tidak berpengaruh secara negatif dan tidaknya signifikan terhadap terhadap Nilai Tukar Petani (Y).hal ininya dapat dilihatnya dari nilainya $\mathrm{t}$ statistik $<\mathrm{t}$ tabel yaitu $0.957110<2.26216$ dan probabilitas sebesar $0.3635>0,05$. Hal ininya berartinya Terima $\mathrm{H}_{0}$ dan Tolak $\mathrm{H}_{1}$ yang berarti Inflasi tidak berpengaruhnya terhadap Nilai Tukar Petani secara negatif dan tidak signifikan.

Selanjutnya Variabel PDRB Sektor Pertanian $\left(\mathrm{X}_{2}\right)$ berpengaruh secara negatifnya dan signifikannya terhadap Nilai Tukar Petani (Y). Hal ininya dapat dilihatnya dari nilainya $\mathrm{t}_{\text {statistik }}>\mathrm{t}$ tabel yaitu $-3.563466>$ 2.26216 dan probabilitas sebesar $0.0061<0,05$. Hal ininya berarti Tolak $\mathrm{H}_{0}$ dan Terima $\mathrm{H}_{2}$ yang berartinya PDRB Sektor Pertanian memiliki pengaruh secara negatifnya dan signifikannya terhadap Nilai Tukar Petani Aceh.

\section{Hasil Uji F-Statistik}

Uji Simultan (Uji F-statistik) digunakannya untuk mengujinya besarnya pengaruh dari seluruh variabelnya independen secaranya bersama-sama atau simultan tehadap variabel dependen. Pembuktian dilakukannya dengan caranya membandingkannya nilai $\mathrm{F}$ kritisnya $\left(\mathrm{F}_{\text {tabel }}\right)$ dengan $\left(\mathrm{F}_{\text {statistik }}\right)$ yang terdapatnya pada tabelnya analysis of variance (Ghozali, 2012). Untuk menentukannya nilai $F_{\text {tabel, }}$, dengan tingkat signifikan yang digunakannya sebesar $5 \%(0,05)$ dengan derajatnya kebebasan (degree of freedom) yaitu $\mathrm{df}=(\mathrm{n}$ k) dan $(\mathrm{k}-1)$ dimana $(12-3=9)$ dan $(3-1=2)$ maka diperoleh $\mathrm{F}_{\text {tabel }}$ sebesar 4.26.

Adapun hasil Pengujian secara Simultan dalam tabel 4.4 diatas yaitu $\mathrm{F}_{\text {statistik }}>\mathrm{F}_{\text {tabel }}$ dengan nilai $6.8023>4.26$ dengan tingkat probabilitas $0.01<0,05$. Maka Tolak $\mathrm{H}_{0}$ dan Terima $\mathrm{H}_{3}$ yang berartinya bahwa dalam penlitian ini, hasil pengujian secara simultan atau secara bersama-samanya variabel Inflasi dan PDRB Sektor Pertanian berpengaruh secara positifnya dan signifikannya terhadap Nilai Tukar Petani Aceh.

\section{Koefisien Determinasi}

Ghozali (2012) meyebutkan analisis ini digunakannya untuk melihatnya seberapa besar variabel bebas mampu menjelaskan variabel terikat. Untuk mengetahui nilai koofisien determinasi dapat diketahui dari nilai adjusted $\mathrm{R}$ square pada tabel model summary. Jika $\mathrm{R}^{2}=0$, maka tidaknya ada sedikitpunnya prosentase sumbangannya pengaruhnya yang diberikannya variabel independennya terhadap variabelnya dependen, variasinya variabel independennya yang digunakannya dalam modelnya tidak menjelaskannya sedikitpun variasinya variabelnya dependen. Sebaliknya, jika $R^{2}=$ 1, makanya presentase sumbangannya pengaruhnya yang diberikannya variabel independennya terhadap variabelnya dependennya adalah sempurnanya, atau variasinya variabel independennya yang digunakannya dalam modelnya menjelaskannya $100 \%$ variasinya variabel dependennya.

Berdasarkan tabel 5 diatas maka hasil pengujian Koefisien Determinasi $\mathrm{R}^{2}$ dengan model regersi linear berganda dapat dilihatnya dari nilainya Adjusted R Square 
sebesar 0.601851 atau sebesar $60.18 \%$. Maka dapatnya disimpulkan bahwanya besarnya pengaruh atau kemampuan variabel inflasi dan PDRB Sektor Pertanian dalam menjelaskannya variabel Nilai Tukar Petani sebesar $60.18 \%$, sisanya sebesar $39.82 \%$ dipengaruhi oleh variabelnya lain diluar model ini.

\section{Koefisien Kolerasi}

Menurut Ghozali (2012) Koefesinkorelasi dinyatakan dalam nilai koefisien korelasi (R). Koefisien Kolerasi ini bertujuannya untuk melihat seberapa besar tingkat kekuatan hubungan antaranya variabel independen dengan variabelnya dependen. Adapun hasil koefisien kolerasi yang diperolehnya dalam penlitian ini yaitu sebesar $R=\sqrt{ } \diamond^{2}=\sqrt{ } 0.6018=0.7757$. Maka dapat disimpulkannya bahwa inflasi dan PDRB Sektor Pertaniannya memiliki hubungan yang kuat secara positif terhadap Nilai Tukar Petani, karena nilai kolerasi sebesar $77,57 \%$ hampir mendekati positif satu (1).

\section{Pembahasan}

\section{Pengaruh Inflasi Terhadap Nilai Tukar Petani}

Hasil Penelitian menunjukkan bahwa Inflasi tidak berpengaruh terhadap Nilai Tukar Petani Aceh secara negatif dan tidak signifikan.Hal ini menunjukkan bahwa inflasi yang terjadi tidak memberikan pengaruh terhadap nilai tukar petani, seharusnya inflasi akan menyebabkan naiknya harga-harga komoditas barang dan jasa yang dikonsumsi masyarakat secara umum. Beragamnya kebutuhaan petani dengan inflasi yang terjadi menyebabkan indek sbiaya hidup itu semakin tinggi sehingga indeks yang harus dibayar bertambah. Semakin tinggi indeks yang harus dibayar maka NTP akan semakin menurun. Selain itu, sifat hasil pertanian yang in-elastis (elastisitas permintaan kurang dari satu) menyebabkan produksi hasil pertanian kurang responsif terhadap kenaikan harga.

Namun dalam kasus ini tidaklah sesuai dengan teori dimana Inflasi tidak berpengaruh terhadap Nilai Tukar Petani Aceh, Hal ini disebabkan laju inflasi yang tidak stabil, ada pada satu tahun yang mengalami inflasi yang tinggi, kemudian ditahun lain inflasi menurun tajamdan drastis, sehingga pergerakan inflasi tidak berpengaruh terhadap Nilai Tukar Petani. Selanjutnya kenaikan inflasi masih tahap inflasi ringan dimana tidak melebihi angka 10, sehingga Stabilnya inflasi tidak meningkatkan harga kebutuhan yang harus dibeli petani dan juga inflasi tidak meningkatkan penerimaan petani akibat peningkatan harga produksi. Hasil penelitian ini juga sejalan dengan penelitiannya yang dilakukannya oleh (Wijaya, 2018) dengan hasilnya penelitian menyebutkan bahwa variabel Inflasi tidak berpengaruh terhadap Nilai Tukar Petani.

\section{Pengaruh PDRB Sektor Pertanian Terhadap Nilai Tukar Petani}

Hasil penelitiannya menunjukkannya bahwa PDRB Sektor Pertaniannya berpengaruh secara negatifnya dan signifikannya terhadapnya Nilai Tukar Petaninya. Hal ini menunjukkan bahwa ketika terjadi peningkatan pada PDRB Sektor Pertanian maka akan membuat Nilai Tukar Petani menurun, dan apabila PDRB Sektor Pertanian menurun maka akan meningkatkan Nilai Tukar Petani.

Produk Domestik Regional Bruto Sektor Pertanian yang adanya di Aceh memberikan kontribusi terbesar dalam pembentukan PDRB total.Besarnya kontribusi tersebut tidak memberikan pengaruhnya yang nyata terhadap kesejahteraan petani.Hal ini dikarenakan ketidak seimbangan nilai konsumsi dengan nilai jual produksi hasil pertaniannya yang menjadifaktor pemicu utama.Kebanyakan petani mengeluarkan konsumsi yang lebihnya besar dari produksinya, sementara nilai jual produksinya tidak mampu mengimbangi besarnya biaya konsumsi.

Konsumsi bersih merupakan jumlah lebih besar dari pada hasil pertanian yang dijual, atau nilai jual hasil pertanian oleh petani relatif lebih kecil dari biaya konsumsi atau dikeluarkan. Seperti halnya hasil pertanian padi sawah, pada saat dijual oleh petani harganya akan berbeda pada saat dibeli untuk dikonsumsi dalam bentuk beras, sehingga biaya konsumsi lebih besar daripada nilai jual hasil produksinya. Besarnya nilai konsumsi maupun harga jual pada akhirnya akan meningkatkan nilai PDRB, akan tetapi pada NTP tidak memberikan pengaruh yang nyata.Sehingga Peningkatan PDRB Sektor Pertanian hanya memberikan Pengaruh yang Negatif, artinya Perubahan yang diberikan PDRB Sektor Pertanian tidak bisa langsung merespon Pertumbuhan Nilai Tukar Petani Aceh.

Hasil penelitian ini juga sejalan dengan penelitian yang dilakukan oleh (Azhar, 2014) yang mana menyatakan bahwa PDRB Sektor Pertanian memiliki pengaruh yang negatif dan siginifikan terhadap Nilai Tukar Petani, yang mana pengaruh dari PDRB Sektor Pertanian masih tidak nyata dalam melihat tingkat kesejahteraan petani yang diukur dari Nilai Tukar Petani. 


\section{KESIMPULAN DAN SARAN}

\section{Kesimpulan}

Berdasarkan hasil penelitian dan pembahasan diatas maka penulis menarik kesimpulan yaitu sebagai berikut :

1. Pengujian secara parsial diperoleh hasil variabel Inflasi tidak berpengaruh secara negatif dan tidak signifikan terhadap Nilai Tukar Petani di Aceh.

2. Pengujian secara parsial diperoleh hasil variabel PDRB Sektor Pertanian berpengaruh negatif dan signifikan terhadap Nilai Tukar Petani di Aceh.

3. Pengujian secara simultan diperoleh hasil variabel Inflasi dan PDRB Sektor Pertanian berpengaruh secara positif dan signifikan terhadap Nilai Tukar Petani di Aceh.

\section{Saran}

Adapun saran yang dapat diberikan penulis dalam penelitian ini yaitu sebagai berikut :

1. Tingkat Inflasi yang terjadi di Aceh dapat menimbulkan dampak positif maupun negatif bagi petani. Inflasi dapat meningkatkan harga hasil pertanian dan juga meningkatkan barang pokok untuk kebutuhan bagi para petani dan petani akan sulit mendapatkan barang modaldalam melakukan produksi. Sehingga diiharapkan kepada pemerintah agar dapat menjaga kestabilan inflasi agar perkembangan tingkat inflasi dapat seimbang dengan harga barang pokok sehingga dapat mensejahterakan petani di Aceh.

2. PDRB Sektor Pertanian yang ada di Aceh memberikan kontribusi paling besar diantara sektorsektor usaha lainnya, namun peningkatan PDRB Sektor Pertanian tidak langsung dapat merespon perkembangan Nilai Tukar Petani, sehingga diharapkan peranan pemerintah agar lebih insentif terhadap para petani agar dapat terjadi keseimbangan antara peningkatan PDRB Sektor Pertanian dengan peningkatan Nilai Tukar Petani, dengan begitu juga dapat membuat tingkat kesejahteraan petani aceh meningkat.

3. Peneliti selanjutnya yang ingin meneliti tentang PDRB sektor pertanian, Inflasi, maupun Nilai Tukar Petani diharapkan mampu meninjau dari aspek yang lebih luas lagi misalkan dengan menambah variabel lain yang lebih berpengaruh terhadap nilai tukar petani sehingga pembahasannya akan lebih mendalam dan spesifik.

\section{DAFTAR PUSTAKA}

andriyani devi \& mulia eka. (2020). Pengaruh nilai tukar petani sub sektor tanaman pangan dan nilai tukar petani sub sektor perikanan terhadap indeks pembangunan manusia di Kabupaten Aceh Utara.

Jurnal Ekonomi Pertanian Unimal, 03(November), 1-8.

https://ojs.unimal.ac.id/index.php/JEPU/a rticle/view/3185

azhar, B. (2014). Pengaruh Kinerja Ekonomi Makro Terhadap Nilai Tukar Petani. Qe Journal, 03(03), 162-178.

\section{Bps Aceh. (2019). Nilai Tukar Petani Provinsi Aceh 2019.}

Faridah Nurul, S. (2016). Analisis FaktorFaktor Yang Mempengaruhi Nilai Tukar Petani Sub Sektor Tanaman Pangan Padi Di Aceh Nurul Faridah 1 * , Mohd. Nur Syechalad 2 1). Jurnal Ilmiah Mahasiswa (Jim), 01(01), 169176.

Ghozali. (2012). Aplikasi Analisis Multivariate Dengan Program Spss. (Edisi Ke-). Universitas Diponegoro.

Ghozali, I. (2006). Aplikasi Analisis Multivarite Dengan Spss, Cetakan Keempat. In Badan Penerbit Universitas Diponegoro: Semarang.

Gujarati, D. (2006). Ekonometri Dasar. Terjemahan: Sumarno Zain. Erlangga.

Gujarati, D. (2009). Dasar-Dasar Ekonomitrika. In Salemba Empat: Jakarta.

Herlianto, D. (2013). Manajemen Investasi Plus Jurus Mendeteksi Investasi Bodong. Penerbit Pustaka Baru.

Mankiw N, G. (2006). Makro Ekonomi, Terjemahan Fitria Liza, Imam Nurmawan. Erlangga.

Nirmala, A. R., Hanani, N., \& Muhaimin, A. W. (2016). Analisis Faktor Faktor Yang Mempengaruhi Nilai Tukar Petani Tanaman Pangan Di Kabupaten Jombang Analysis Of Factors That Affecting Farmers Exchange Rage Of Food Crops In Jombang. Jurnal 
Habitat, 27(2), 66-71.

Https://Doi.Org/10.21776/Ub.Habitat.2

016.027.2.8

Riyadh, M. I. (2015). Analisis Nilai Tukar Petani Komoditas Tanaman Pangan Di Sumatera Utara ( Analysis Of Farmers Term Of Trade Of Crops Commodities In North Sumatra ). Jurnal Ekonomi \& 
Kebijakan Publik, 06(01), 17-32.

Simanjuntak, M., \& Bhakti, A. (2018). Pengaruh Pdrb Sektor Pertanian, Nilai Tukar Petani Dan Investasi Sektor Pertanian Terhadap Penyerapan Tenaga Kerja Sektor Pertanian Provinsi Jambi. E-Jurnal Ekonomi Sumberdaya Dan Lingkungan, 7(1), 112.

Sukirno, S. (2012). Makroekonomi Teori Pengantar. Pt Rjagrafindo Persada.

Sunyoto, D. (2011). Metodelogi Penelitian Ekonomi. Cetakan Pertama. In Caps: Yogyakarta.

Wardhani, Kusuma, S. C. (2017). Analisis FaktorFaktor Yang Mempengaruhi Nilai Tukar Petani Tanaman Pangan Di Pulau Jawa. Univeristas Diponegoro Semarang.

Wijaya, A. R. (2018). Determinan Nilai Tukar Petani Provinsi-Provinsi Di Pulau Sumatera Periode 2010-2015. In Program Studi Ekonomi Syari'ah. Universitas Islam Negeri Sunan Kalijaga Yogya. 